\title{
Global oil market and the U.S. stock returns
}

\author{
Maryam Ahmadi ${ }^{\text {a, }}{ }^{*}$, Matteo Manera ${ }^{\mathrm{b}}$, Mehdi Sadeghzadeh ${ }^{\mathrm{c}}$ \\ ${ }^{a}$ Lombardy Advanced School of Economic Research (LASER), Italy \\ ${ }^{\mathrm{b}}$ University of Milan-Bicocca and Fondazione Eni Enrico Mattei (FEEM), Italy \\ ${ }^{\mathrm{c}}$ Institute for Management and Planning Studies (IMPS), Iran and Bocconi University, Italy
}

\section{A R T I C L E I N F O}

\section{Article history:}

Received 2 November 2015

Received in revised form

3 May 2016

Accepted 22 August 2016

Available online 15 September 2016

\section{JEL classifications:}

Q3 Q31 Q43

C22

G15

\section{Keywords:}

Stock returns

Oil price

Structural vector autoregression

\begin{abstract}
A B S T R A C T
This paper provides an analysis of the link between the oil market and the U.S. stock market returns at the aggregate as well as industry levels. We empirically model oil price changes as driven by speculative demand shocks along with consumption demand and supply shocks in the oil market. We also take into account in our model all the factors that affect stock market price movements over and above the oil market, in order to quantify the pure effect of oil price shocks on returns. The results show that stock returns respond to oil price shocks differently, depending on the causes behind the shocks. Impulse response analysis suggests that consumption demand shocks are the most relevant drivers of the stock market return, relative to other oil market driven shocks. Industry level analysis is performed to control for the heterogeneity of the responses of returns to oil price changes. The results show that both cost side and demand side effects of oil price shocks matter for the responses of industries to oil price shocks. However, the main driver of the variation in industries' returns is the shock to aggregate stock market. () 2016 Elsevier Ltd. All rights reserved.
\end{abstract}

\section{Introduction}

The impacts of oil price changes on the economic indicators are very important in studying the connection between oil and the economy. The prevailing approach in the literature is to analyze this connection by investigating the impacts of oil price shocks on macroeconomic and financial variables such as stock market returns. Several empirical studies document strong evidence connecting oil price shocks and stock market returns. For example, $[7,28]$ find a negative effect of an oil price increase on aggregate real stock returns. [10] concludes that the connection between oil price and stock market returns is nonlinear. Some studies have done sector analysis and concluded that the oil-related industries appreciate after an oil price increase while oil using industries depreciate after the same change (see e.g. Refs. $[3,4,39]$ ). On the other hand, there are studies concluding that there is not a significant connection between oil market and stock market (for example $[8,20,38])$.

There is a consensus in the literature that oil price is not

\footnotetext{
* Corresponding author.

E-mail addresses: maryam.ahmadi@unimi.it (M. Ahmadi), matteo.manera@ unimib.it (M. Manera), m.sadeghzadeh@imps.ac.ir (M. Sadeghzadeh).
}

exogenous and its determining factors are supply and demands for oil and for other industrial commodities (see e.g. Refs. [1,5,13,17, $24,26])$. [17,24,27] argue that the endogeneity of the price of oil with respect to macroeconomy is essential in studying the effect of oil price on any economic variable. In particular Kilian and Park [27] study the effects of oil price changes on the U.S. stock market return taking into account the determining factors of the oil market, including supply and demand. The results they document suggest that the response of the stock market returns to oil price shocks caused by the demand side of the economy is the most significant one. What is missing in the current literature assessing the effects of oil market shocks on the stock market returns is taking into account the underlying factors driving returns in the stock market. According to the [14], the price of a share is equal to the discounted sum of expected future dividends. [32] argue that the underlying source of a firm's value is the firm's earnings as it fund dividends. Therefore, the systematic factors influencing stock prices are those impacting expected earnings and the discount rate (Fama [12]). Accordingly, numerous number of papers studied the effect of various macroeconomic and/or stock market related variables on stock market return. Goyal and Welch [15] comprehensively study the performance of the variables that are suggested in literature to be stock market return predictors in explaining the future values of the returns. 
This paper tries to fill this gap by taking into account the determinant factors of stock market return along with those of oil market in studying the connection between the two markets. The econometric framework of this paper is based on a structural vector autoregressive (SVAR) model developed by Ref. [26] that enables the identification of the speculative demand component of the oil price shocks along with supply and consumption demand components by considering the determining variables of the global market for crude oil, including the global production of oil, consumption demand for oil, inventory demand for oil and the real price of oil. Identifying the speculation component of the price of oil is very important since as documented in Refs. [19,26,27], it plays an important role in the fluctuations of oil price. We augment this framework by including the determining factors of the stock market return to the structural VAR model to capture any fluctuation of the return that is driven by stock market related variables which are unrelated to oil market.

Stock market related variables are taken from the long list of predicting factors documented by Ref. [15] which includes dividend price ratio, stock return volatility, default spread, long term rate of return, corporate bond returns and net equity expansion. These variables are shown to have very significant explanatory power towards stock market return. The results documented by this paper suggest that the effect of oil market on stock market return is indeed overestimated if the endogeneity of stock market return with respect to stock market related variables is not taken into account. The findings show that there is a negative relation between stock market return and oil price changes driven by a shock to speculative demand for oil. An oil price increase due to an oil supply shock does not significantly affect stock market return while its effect is mixed when global demand shock raises the price of oil. It raises the market return for ten months and lowers it afterwards. According to results from forecast error variance decomposition (FEVD) of the stock market return, in the long-run on average, 16\% of the variations of the U.S. real stock return is explained by the structural shocks in the global crude oil market. However, if we exclude the stock market related variables from the model, the explanatory power of oil market shocks towards the variations in stock return raises to more than 18\% in FEVD analysis. This result reflects how a misspecified model would overestimate the role of oil market in explaining variations in stock market.

Different industries are always heterogeneous. They are different in energy consumption, their demand for oil and their consumers' dependence on oil. Considering the heterogeneity of sectors is shown to be very important in the analysis of the economic variables and their relationship (e.g. Refs. [9,42]). In this study, industry level analysis is performed to control for the heterogeneity among sectors in response to oil price changes and to better investigate the transmission channels of oil market shocks to stock market. However, this paper is not the first to preform such an analysis. For example, [3,4,27,29,40], among others, have examined the effects of oil price changes on sector level returns in the U.S. and Europe stock markets using various econometric techniques. The consensus in the literature is that an oil price increase affects industries through the supply for industry inputs and the demand for final product. On the supply side, this shock increases the input cost of industries as well as the transportation cost. On the demand side, depending on the cause behind the shock and on the sectors, it could increase or decrease the demand for the industries' output. If the oil price increase is driven by better economic activity, it raises the demand for all industrial commodities, while a speculative demand shock decreases the demand for manufacturing industries and increase the demand for substitutionary energy sectors like coal, as well as precious metals as being a safe haven to avoid increasing risk from uncertainty in the oil market.
The common practice in the empirical studies examining the effect of oil market on sectors of stock market is to analyze a specific sector in the stock market in isolation of the other sectors or the market as a whole. The conclusion of such studies is therefore based on the connection between the oil market and an industry's return in the stock market (e.g. Ref. [27]) or the commodity market (e.g. Ref. [41]). This view is particularly of high importance since it provides a clearer image of the transmission channel through industries as opposed to the outcome effect on the stock market where positive or negative effects on the sectors counterbalance. However, the results of such analyses are heavily postulated on the presumption that the return of a sector in stock market only responds to the shocks occurred in oil market and is uncorrelated to the return of other sectors or market wide shocks. This presumption does not seem to be credible in the presence of supply-demand chain for input-output among sectors (see for example [31]), or market wide systematic shocks like global financial crisis. The latter is particularly very important as concluded by Ref. [23], who investigated the impacts of industry level and market wide shocks in equity markets. We argue that industry specific shocks as well as market wide shocks should be taken into account in the sectoral analysis. For this objective, we augment the structural VAR model where oil market variables are included as well as an industry's return, by adding an index of market return. For each industry we construct the index for market return by making a weighted average of the returns of all the selected industries, excluding the industry in question, where weights are proportional market values of each industry.

The findings from sector level analysis show that industries are affected through both the cost side and the demand for final product. Therefore, although the total cost of energy matters, it is not enough to explain differences in the responses of stock returns across industries. This result is in contrast to the interpretation of oil price shocks as input cost shocks. For many industries, specially less oil intensive ones, the transmission of oil price shocks to their returns is driven more by shifts in the demand for goods and services, rather than the cost of production. Examples are consumer goods and services, entertainments and retail industries. More interestingly, the results imply that in response to an oil price increase that is due to a speculative demand shock in oil market, auto, consumer goods and steel industries depreciate while precious metals appreciates and oil industry is unaffected. This result could be interpreted as a re-balance in market participants' investment portfolio, followed by an unexpected increase in the speculation in the oil market. All the industries appreciate if the reason of oil price increase is global demand shock.

The rest of the paper is set out as follows. Section 2 reviews literature related to the current research. Section 3 describes the data. In Section 4 the structural VAR methodology is described. The results of estimation of the structural VAR model for the U.S. aggregate stock market return are discussed in Section 5. In Section 6 sectoral analysis is carried out by assessing the impulse responses and forecast error variance decomposition. Some concluding remarks are given in Section 7.

\section{Literature review}

The relationship between oil price shocks and stock market returns is studied broadly in the literature. A group of studies applying econometric models assesses the link between the stock market return and different variables including oil price. Charles and Gautam [7], test the response of stock market return to oil price changes based on the cash-flow dividend valuation model on quarterly data for the U.S., Canada, UK and Japan. They find that in the post-war period, the effects of an oil price shock on stock 
market return in Canada and the U.S. are through its impact on real cash flows, while the results for Japan and the UK are not conclusive. Sadorsky [37] develops a Vector Autoregressive (VAR) model with GARCH effects to American monthly data of oil price, stock market return, short-term interest rate and industrial production over the period 1947-1996. He shows that oil price plays an important role in variations of the U.S. aggregate real stock market return. Odusami [33] analyzes the relationship between oil price and the U.S. stock market by employing an asymmetric GARCHjump model. Using daily data from January 1996 to December 2005 he finds a nonlinear negative relationship between oil price shocks and the U.S. stock market return. Using an unrestricted vector autoregressive (VAR) model, Huang et al. [20] find no relationship between oil price and the S\&P500 market index. Park and Ratti [34] use an unrestricted VAR with the four variables and find that, over 1986:1-2005:12, an oil price shocks has a negative impact on real stock market return in the U.S. and 12 European countries and a positive impact in Norway as an oil exporter. Dhaoui and Khraief [11] employ an EGARCH-in-M model to examine whether oil price shocks impact stock market return. They use monthly data for eight developed countries from January 1991 to September 2013 and find that an oil price shock negatively affects stock market return in the U.S., Swiss, France, Canada, U.K., Australia and Japan. However they find no impact of oil price changes on stock market of Singapore.

Some studies, consider the endogeneity of the price of oil with respect to macroeconomic and global oil market variables. They take into account the determining factors of the real price of oil in the analysis of the effects of oil price shocks on stock market returns. $[2,27]$ assess the effects of oil price shocks on real stock market returns by employing a structural vector autoregressive model to decompose oil price changes into three components including oil supply shock, oil-specific demand shock and global demand shock. Kilian and Park [27] consider the U.S. real stock market returns from 1973:2 to 2006:12 and document that the response of the U.S. real stock market return to an oil price shock depends on the underlying shock that drives the oil price shock. According to their results, the response of the U.S. stock market return to an oil supply shock is not significant while a global demand shock has positive and an oil-specific demand shock has negative impacts on real stock market return. Apergis and Miller [2], using data for the period from 1981 to 2007 of eight countries, Australia, Canada, France, Germany, Italy, Japan, the U.K. and the U.S., find that international stock market returns do not respond in a large way to oil market shocks. Oil supply shocks, global demand shocks and oil-specific demand shocks have significant but small effects on stock-market return in most countries. [36] develops a method for classifying oil price changes as supply or demand driven and documents that demand shocks are strongly positively correlated with market returns, while supply shocks have a strong negative correlation.

Moreover, many studies focus on industry level data to provide a clearer understanding of the transmission channel through which oil price shocks affect stock market returns. Lee and Ni [29] study the effects of oil price shocks on demand and supply in the U.S. industries by applying a structural vector auto regressive model. They conclude that oil price shocks have negative effects upon the U.S. industries. For more oil intensive industries, like industrial chemicals, oil price shocks mainly reduce supply while for many other industries oil price shocks mainly reduce demand. Kilian and Park [27] investigate the impacts of oil price shocks on the return of four industries: petroleum and natural gas, automobiles and trucks, retail and precious metals industries. They find that the effects of oil price shocks on the U.S. industries' returns differ across industries and also depending on the cause of the shock. They suggest that oil price shocks are shocks to the demand for industries rather than being supply shocks. $[3,4,40]$ using European data with different econometric techniques, find that the responses of stock returns to oil price shocks differ greatly depending on the sectors. On the industry level analysis, [36] concludes that the negative effects of supply shocks are concentrated in industries which produce consumer goods, and are also strongest for oil importing countries.

This paper extends the previous literature by taking into account the endogeneity of the real price of oil and the real stock market return with respect to macroeconomic and their own market variables. We investigate the link between oil price and the U.S. real stock market return in the aggregate and industry levels. The econometric framework is based on a structural vector autoregressive model. Our object is to provide a comprehensive analysis of the effects of supply and demands components of an oil price shock on the U.S. stock market return in the presence of stock market determinants. Structural VAR framework has two advantages for this object. First, it allows to identify the speculative demand component of the oil price shocks along with supply and consumption demand components and second, we can include the determining factors of the stock market return to the analysis. The latter is to capture any fluctuation of the return that is driven by stock market related variables which are unrelated to the oil market.

\section{Data}

The data we use in this study is monthly and covers the period 1973:3-2013:12. As described in the previous section, two types of variables are employed, variables related to the U.S. stock market and variables related to the global oil market.

Global oil market variables consist of global crude oil production, global crude oil inventories, real price of crude oil and finally a measure for global trade. Data on global crude oil production is available in the monthly energy review of the Energy Information Administration (EIA). The real price of crude oil is the U.S. refiners' acquisition cost for imported crude oil and is reported by the EIA. We extrapolate this series from 1974:1 back to 1973:3 to cover the whole sample period following [6], and deflate it by the U.S. consumer price index. Given the lack of data on crude oil inventories for all countries, following $[25,26]$, we employ the data for the U.S. crude oil inventories scaled by the ratio of OECD petroleum stocks over the U.S. petroleum stocks as a proxy for global crude oil inventories. ${ }^{1}$ We use a measure of global industrial activity, introduced by Ref. [24], to proxy global demand for crude oil. This measure is based on the global dry cargo shipping rates which reflects the global business cycle and measures consumption demand for oil and all industrial commodities.

Stock market variables consist of the U.S. aggregate stock market and industries return as well as other related variables. The aggregate U.S. stock return is from is from the Center for Research in Security Prices (CRSP) which is a value-weighted market portfolio including NYSE, AMEX, and Nasdaq stocks. The real stock market return is obtained from the aggregate U.S. stock return deflated by the U.S. consumer price index. The industry level returns are available by Kenneth French. ${ }^{2}$ This data is derived from the CRSP database and therefore are consistent with the aggregate stock return series. The industries we analyze include precious metals, steel, consumer goods (household), aircraft, automobile and trucks,

\footnotetext{
1 The data for this proxy of the global crude oil inventories, and for other three oil market variables are also available in Journal of Applied Econometrics data archive. 2 Available at http://mba.tuck.dartmouth.edu/pages/faculty/ken.french/ datalibrary.html.
} 
transportation, chemicals and petroleum and natural gas. We intend to satisfy a set of criteria to choose these industries. First, any industry chosen is supposed to be affected by oil market through either of the channels mentioned above. Second, the selected industries account for relatively high (more than thirty percent) fraction of the market value. Data on other stock market variables, including dividend price ratio, stock return volatility, default spread, long term rate of return, corporate bond returns and net equity expansion are available by Amit Goyal. ${ }^{3}$

\section{Methodology}

A structural vector autoregressive (SVAR) model is used in this paper to investigate the impact response of the U.S. stock market returns to oil market shocks, namely, oil supply shock, global demand shock and speculative demand shock. The structural VAR model is the following:

$A_{0} y_{t}=\alpha+\sum_{i=1}^{24} A_{i} y_{t-i}+B X_{t}+\varepsilon_{t}$

where $y_{t}$ is the vector of endogenous variables including the percent change in global crude oil production, global real economic activity, the change in global crude oil inventory, the real price of crude oil and the U.S. real stock return. $X_{t}$ is the vector of stock market variables that are main drivers of stock returns including dividend price ratio, stock return volatility, default spread, long term rate of return, corporate bond returns and net equity expansion. This vector is treated as an exogenous variable to the VAR system. Following [26], we assume that the vector of structural shocks, $\varepsilon_{t}$, consists of the following shocks. The first shock, oil supply shock, is an unanticipated shift in the percentage change of the global production of crude oil. The Second shock, consumption demand shock (global demand shock), is a sudden change in the demand for crude oil and other industrial commodities. The third shock, speculative demand shock, is the shock to the demand for the above-ground oil inventories. This shock captures the changes in speculative demand for oil inventories that arises when the future oil supply is uncertain. The forth shock is called the residual shock and captures the short-run unanticipated change in the real price of oil which is not driven by the first three shocks. An example would be an abrupt change in the weather which increases the oil price in the short-run but it does not affect the other driving factors of the oil market. Finally, the last shock captures innovations in the real stock returns which is not driven by the factors operating inside the financial markets.

We estimate the VAR system with 24 lags. Applying 24 months of lags is consistent with $[18,27]$ who argue that allowing for high lag order is crucial in capturing the transmission of the structural shocks in the oil market. They provide evidence that moving cycles in the oil market are very slow and a low number of lag would fail to capture the whole dynamics of the cycle. The alternative way of setting the lag order is testing the goodness of fit using information criteria. However, some researchers argue against the validity of such methods specially when there is a prior on the number of lags. For example Leeb and Potscher [30] argue that any lag order selection based on data used in the analysis invalidates inference. Ivanov and Kilian [22] conclude that where one has no prior information about lag length, for structural impulse responses in monthly VAR models, the AIC could be a good approach. However, according to [18] there are strong claims about the value of lag

\footnotetext{
3 http://www.hec.unil.ch/agoyal/.
}

order in the oil market based on prior studies and the AIC estimates would make a lower bound.

The reduced-form representation of Equation (1) is given by:

$y_{t}=A_{0}^{-1} \alpha+\sum_{i=1}^{24} A_{0}^{-1} A_{i} y_{t-i}+A_{0}^{-1} B X_{t}+e_{t}$

and the vector of residuals, $e_{t}$, has the following relation with the vector of structural shocks, $\varepsilon_{t}$ :

$e_{t}=A_{0}^{-1} \varepsilon_{t}$

In order to identify structural innovations from the reducedform residuals, we impose short-term exclusive restrictions on the matrix $A_{0}^{-1}$ as follows.

$$
\begin{aligned}
\left(\begin{array}{c}
e_{1 t}^{\Delta \text { global oil production }} \\
e_{2 t}^{\text {global real activity }} \\
e_{3 t}^{\Delta \text { global oil inventory }} \\
e_{4 t}^{\text {real price of oil }} \\
e_{5 t}^{\text {real stock return }}
\end{array}\right)= & {\left[\begin{array}{ccccc}
a_{11} & 0 & 0 & 0 & 0 \\
a_{21} & a_{22} & 0 & 0 & 0 \\
a_{31} & a_{32} & a_{33} & 0 & 0 \\
a_{41} & a_{42} & a_{43} & a_{44} & 0 \\
a_{51} & a_{52} & a_{53} & a_{54} & a_{55}
\end{array}\right] } \\
& \times\left(\begin{array}{c}
\varepsilon_{1 t}^{\text {oil supply shock }} \\
\varepsilon_{2 t}^{\text {global demand shock }} \\
\varepsilon_{3 t}^{\text {speculative shock }} \\
\varepsilon_{4 t}^{\text {residual shock }} \\
\varepsilon_{5 t}^{\text {stock market shock }}
\end{array}\right)
\end{aligned}
$$

The identifying restrictions are based on the four assumptions. First, we assume that in short-run, that is within a month after a shock, changes in global oil production do not respond to global demand shock and other oil market shocks, as well as stock market shocks. This assumption complies with the real world because adjustment in oil production plan is very costly. The second assumption is that within a month, the increase in price of oil that is caused by speculative demand shock or other oil market shocks does not affect global real economic activity. The third assumption is that, in short-run, global oil inventory responds only to supply, global demand and speculative demand shocks. Finally, we assume that oil market variables do not respond to the shocks in the stock market.

In order to see how the results change if the stock market related variables are excluded from the model, we compare the results of the model 1 with the second model:

$A_{0} y_{t}=\alpha+\sum_{i=1}^{24} A_{i} y_{t-i}+\varepsilon_{t}$

where all the variables are defined as in model 1 . Model 3 is the typical model applied in literature in the sense that it assumes that all the fluctuations in the stock market return are caused by the oil market. The results presented in the next sections will illustrate how this presumption leads to overestimation of the role of the oil market in expiating the stock market.

Model 1 is augmented and applied to analyze the connection between industries and the oil market. We modify model 1 in two directions. The first change is obviously adding the real return of the selected industries to the vector of endogenous variables, $y_{t}$, in model 1. Each industry is analyzed separately by estimating the model using the industry's return data. The second modification is that for each industry we construct an index to proxy the market return. The aim of this procedure is to exclude the contribution of the industry under consideration from the market return and 

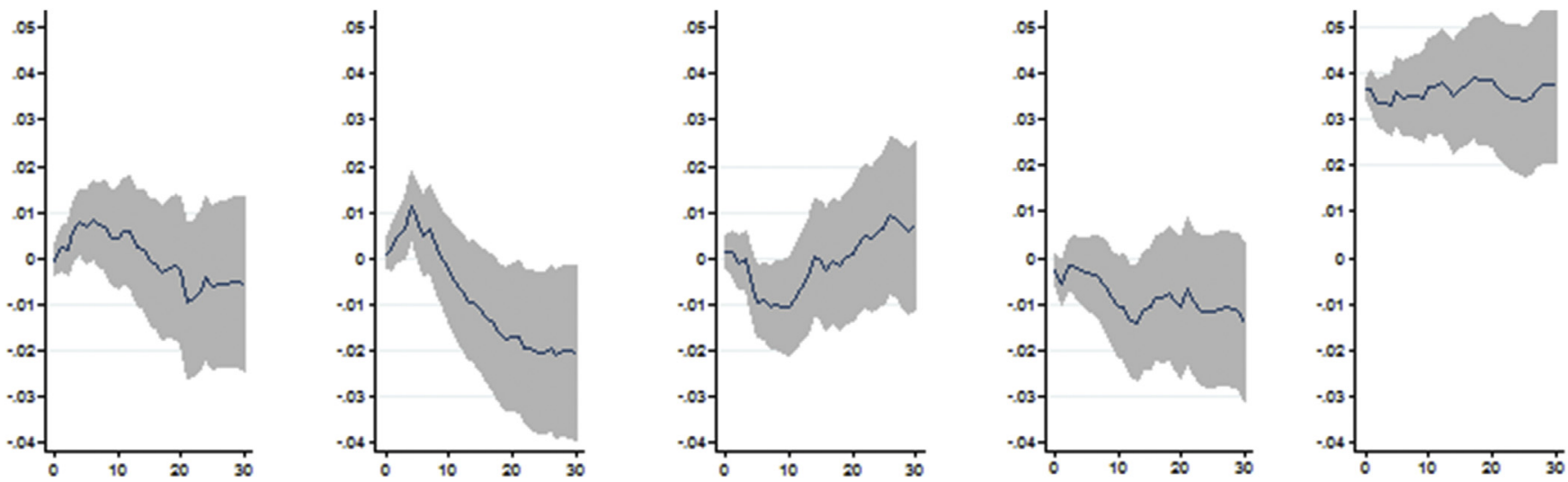

Oil supply shock Global demand shock Speculative shock

\section{Residual shock Stock market shock}

Fig. 1. Structural impulse responses from the estimation of model 1.

facilitate the identification of the market wide shocks and the industry specific shocks. The index is constructed as the weighted average of the real return of all the industries excluding the industry under consideration, where the weights are the relative market value of each industry. The identification scheme is described in relation 4 .

$$
\begin{aligned}
\left(\begin{array}{c}
e_{1 t}^{\Delta \text { global oil production }} \\
e_{2 t}^{\text {global real activity }} \\
e_{3 t}^{\Delta \text { global oil inventory }} \\
e_{4 t}^{\text {real price of oil }} \\
e_{5 t}^{\text {real stock return }} e_{6 t}^{\text {real industry return }}
\end{array}\right)= & {\left[\begin{array}{cccccc}
a_{11} & 0 & 0 & 0 & 0 & 0 \\
a_{21} & a_{22} & 0 & 0 & 0 & 0 \\
a_{31} & a_{32} & a_{33} & 0 & 0 & 0 \\
a_{41} & a_{42} & a_{43} & a_{44} & 0 & 0 \\
a_{51} & a_{52} & a_{53} & a_{54} & a_{55} & 0 \\
a_{61} & a_{62} & a_{63} & a_{64} & a_{65} & a_{66}
\end{array}\right] } \\
& \left(\begin{array}{c}
\text { oil supply shock } \\
\varepsilon_{1 t}^{\text {global demand shock }} \\
\varepsilon_{2 t}^{\text {speculative shock }} \\
\varepsilon_{3 t}^{\text {residual shock }} \\
\varepsilon_{4 t}^{\text {stock market shock }} \\
\varepsilon_{5 t}^{\text {industry specific shock }} \\
\varepsilon_{6 t}^{\text {st }}
\end{array}\right)
\end{aligned}
$$

The identification assumptions in relation 2 are preserved in relation 4 . The additional identifying restriction in relation 4 compared to relation 2 is that industry specific shocks do not affect aggregate market return within a month after the shock. The constructed index to proxy market return legitimizes such assumption because now any possible correlation between the market return index and an industry return should be driven by market wide shocks, like a surprising shift in the interest rates set by government and not industry specific shocks, like technological breakthroughs.

\section{Estimation results}

Fig. 1 depicts the impulse responses of the U.S. real stock market return to the structural shocks in the crude oil market and the stock market shock resulted from estimation of the model 1 . The impulse responses imply that an unexpected oil supply disruption does not significantly affect the real stock market return. On the other hand, an unanticipated positive shock in the global demand for oil has a positive effect on the real stock return which is persistent for about 9 months. This result is expected as a positive global demand shock is caused by an increase in real economic activity, reflected as a positive change in the real stock return. Therefore, in the short run, the U.S. stock market appreciates even though the real price of oil increases. The only cause of an oil price increase that makes a depreciation in the U.S. aggregate real stock return is speculative demand shock. A positive speculative demand shock causes a significant and persistent negative effect on the U.S. real stock return. This result is not surprising since investors decrease their demand for stocks as they rebalance their portfolios against the stock market by investing more on the oil market.

Table 1 reports the contribution of each shock to variations in the stock market return. Forecast error variance decomposition analysis indicates that in the long run, the explanatory power of all oil market shocks are larger than in the short run. In the long run (30 months after the shock), $16 \%$ of the variations of the U.S. real stock market return is explained by the structural shocks in the global crude oil market. Consumption demand shock with $5 \%$ and speculative demand shock with $4 \%$ show the largest contributions to the variability of returns and oil supply shocks explain only $2.5 \%$. This result is consistent with the findings of $[19,27]$ that speculation and consumption demand have deep impacts on oil price fluctuations.

To see how the presence of the stock market determinants is important in studying the connection between the stock market and the oil market, Fig. 2 and Table 2 present the impulse responses and the results of variance decomposition resulted from model 3. The results of model 3 suggest that the dynamics of the responses of the stock returns to the oil market shocks is similar to the results obtained from model 1 . Compared to oil supply shocks, consumption demand and speculative demand shocks play more important role in explaining the variation of the U.S stock returns. However, the important difference is that the contribution of all oil market shocks is larger in model 3 compared to model 1. In the long-run (30 months after the shock), more than $18 \%$ of the variations of the U.S. real stock market return is explained by the shocks in the oil market. This result provides evidence that omitting stock market variables leads us to overestimate the role for oil market shocks in explaining the variations in the stock market return.

\section{Industries and the oil market}

In this section, the structural analysis is performed based on the industry level data for both oil intensive and non-oil intensive sectors. ${ }^{4}$ This analysis is crucial to find out the channels through which oil price shocks affect aggregate stock market returns. As

\footnotetext{
${ }^{4}$ We use the data for 49 industry portfolios that is available with a detailed definition of the industries by Kenneth French.
} 
Table 1

Variance decomposition of the U.S. real stock market return from estimation of model 1.

\begin{tabular}{|c|c|c|c|c|c|}
\hline Horizon & Supply shock & Global demand shock & Speculation shock & Other oil shocks & Other stock mrkt shocks \\
\hline 2 & 0.52 & 0.16 & 0.14 & 1.08 & 98.09 \\
\hline 3 & 0.51 & 0.71 & 0.44 & 2.031 & 96.31 \\
\hline 12 & 2.26 & 6.07 & 3.46 & 2.85 & 85.36 \\
\hline 13 & 2.23 & 6.31 & 3.65 & 3.32 & 84.49 \\
\hline 15 & 2.99 & 6.39 & 5.08 & 3.68 & 81.86 \\
\hline
\end{tabular}
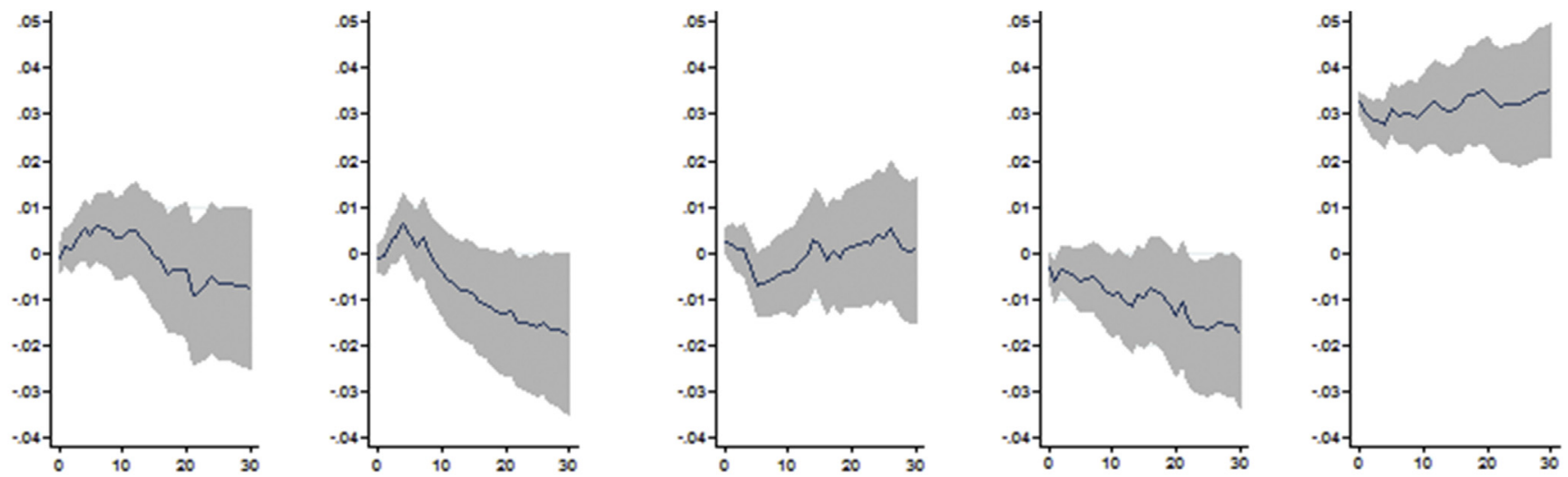

Oil supply shock

Global demand shock Speculative shock

Residual shock

Stock market shock

Fig. 2. Structural impulse responses from the estimation of model 2.

Table 2

Variance decomposition of the U.S. real stock market return from estimation of model 2.

\begin{tabular}{|c|c|c|c|c|c|}
\hline Horizon & Supply shock & Global demand shock & Speculation shock & Other oil shocks & Other stock mrkt shocks \\
\hline 2 & 0.59 & 0.15 & 0.63 & 1.88 & 96.75 \\
\hline 3 & 0.61 & 1.08 & 0.77 & 2.62 & 94.92 \\
\hline 12 & 2.20 & 5.13 & 3.27 & 3.06 & 86.34 \\
\hline 13 & 2.18 & 5.11 & 3.66 & 3.36 & 85.69 \\
\hline 15 & 2.58 & 5.15 & 4.25 & 3.83 & 83.92 \\
\hline
\end{tabular}

industries do not respond homogeneously to oil price shocks, aggregate stock market responses may mask the performance of different sectors which are not necessarily uniform. Some sectors may be affected more severely by these shocks due to the high level of oil usage as an input for manufacturing, or the change in demand for their output. The demand for the output of industries changes not only by end-user consumers but also by some other industries that use this output as an intermediate good. The latter generates a link between some individual sectors caused by an oil related shock which we would call an indirect effect of an oil shock. The indirect

Table 3

Results of regressing each industry return on the stock market variables without and with inclusion of the index for aggregate stock market return.

\begin{tabular}{|c|c|c|c|c|c|c|c|c|}
\hline & hshld & hshld & Steel & Steel & Autos & Autos & Aero & Aero \\
\hline Market return & & $\begin{array}{l}0.77^{* * *} \\
(22.04)\end{array}$ & & $1.27^{* * *}(23.80)$ & & $1.045^{* * *}(19.27)$ & & $1.093^{* * *}(22.40)$ \\
\hline $\begin{array}{l}\text { Dividend } \\
\text { price ratio }\end{array}$ & $\begin{array}{l}-0.019^{* * *} \\
(-3.43)\end{array}$ & $\begin{array}{l}-0.00715 \\
(-1.85)\end{array}$ & $-0.0259^{* *}(-3.04)$ & $-0.007(-1.19)$ & $-0.0256^{* *}(-3.28)$ & $-0.0102(-1.72)$ & $-0.0173 *(-2.29)$ & $-0.000867(-0.16)$ \\
\hline Return volatility & $\begin{array}{l}-3.176^{* * *} \\
(-7.18)\end{array}$ & $\begin{array}{l}-0.531 \\
(-1.59)\end{array}$ & $-5.174^{* * *}(-7.44)$ & $-0.844(-1.67)$ & $-5.081^{* * *}(-7.94)$ & $-1.544^{* *}(-3.00)$ & $-4.383^{* * *}(-7.11)$ & $-0.653(-1.41)$ \\
\hline Default spread & $\begin{array}{l}1.771^{* *} \\
(3.11)\end{array}$ & $\begin{array}{l}0.615 \\
(1.51)\end{array}$ & $2.147^{*}(2.39)$ & $0.233(0.38)$ & $3.485^{* * *}(4.23)$ & $1.960^{* *}(3.13)$ & $2.121^{* *}(2.67)$ & $0.472(0.84)$ \\
\hline $\begin{array}{l}\text { Long term } \\
\text { rate of ret }\end{array}$ & $\begin{array}{l}-0.146 \\
(-1.03)\end{array}$ & $\begin{array}{l}0.229^{*} \\
(2.25)\end{array}$ & $-1.210^{* * *}(-5.43)$ & $-0.61^{* * *}(-3.96)$ & $-1.118^{* * *}(-5.46)$ & $-0.622^{* * *}(-3.98)$ & $-0.593^{* *}(-3.00)$ & $-0.0760(-0.54)$ \\
\hline $\begin{array}{l}\text { Corporate } \\
\text { bond ret }\end{array}$ & $\begin{array}{l}0.590^{* * * *} \\
(3.74)\end{array}$ & $\begin{array}{l}-0.104 \\
(-0.90)\end{array}$ & $1.417^{* * *}(5.71)$ & $0.283(1.62)$ & $1.394^{* * *}(6.11)$ & $0.461^{*}(2.59)$ & $0.929^{* * *}(4.23)$ & $-0.0431(-0.27)$ \\
\hline $\begin{array}{l}\text { Net equity } \\
\text { expansion }\end{array}$ & $\begin{array}{l}-0.126 \\
(-1.12)\end{array}$ & $\begin{array}{l}-0.0578 \\
(-0.73)\end{array}$ & $0.0344(0.20)$ & $0.150(1.25)$ & $0.0271(0.17)$ & $0.125(1.02)$ & $-0.0690(-0.44)$ & $0.0293(0.27)$ \\
\hline Constant & $\begin{array}{l}-0.0756^{* *} \\
(-3.19)\end{array}$ & $\begin{array}{l}-0.0316 \\
(-1.87)\end{array}$ & $-0.101^{* *}(-2.71)$ & $-0.0274(-1.08)$ & $-0.115^{* * *}(-3.36)$ & $-0.0557^{*}(-2.14)$ & $-0.0669 *(-2.03)$ & $-0.00306(-0.13)$ \\
\hline $\mathrm{r} 2$ & 0.1770 & 0.5902 & 0.1909 & 0.6280 & 0.2157 & 0.5569 & 0.1493 & 0.5833 \\
\hline
\end{tabular}

$t$ statistics in parentheses.

${ }^{*} p<0.05,{ }^{* *} p<0.01,{ }^{* * *} p<0.001$. 
Table 4

Results of regressing each industry return on the stock market variables without and with inclusion of the index for aggregate stock market return.

\begin{tabular}{|c|c|c|c|c|c|c|}
\hline & Gold & Gold & Oil & Oil & Trans & Trans \\
\hline Market return & & $0.497^{* * *}(4.22)$ & & $0.647^{* * *}(12.91)$ & & $1.02^{* * *}(27.28)$ \\
\hline Dividend price ratio & $-0.0163(-1.25)$ & $-0.00881(-0.68)$ & $-0.0136^{*}(-2.12)$ & $-0.00338(-0.61)$ & $-0.0153^{*}(-2.36)$ & $0.00003(0.01)$ \\
\hline Return volatility & $-2.706^{*}(-2.54)$ & $-1.006(-0.90)$ & $-2.77^{* * *}(-5.29)$ & $-0.511(-1.05)$ & $-3.63^{* * *}(-6.86)$ & $-0.133(-0.37)$ \\
\hline Default spread & $3.052 *(2.22)$ & $2.300(1.69)$ & $0.621(0.92)$ & $-0.470(-0.80)$ & $1.797^{* *}(2.64)$ & $0.255(0.59)$ \\
\hline Long term rate of ret & $-0.477(-1.40)$ & $-0.240(-0.71)$ & $-0.56^{* * *}(-3.36)$ & $-0.262(-1.79)$ & $-0.484^{* *}(-2.86)$ & $0.00365(0.03)$ \\
\hline Corporate bond ret & $0.855^{*}(2.25)$ & $0.411(1.06)$ & $0.815^{* * *}(4.36)$ & $0.232(1.38)$ & $0.855^{* * *}(4.54)$ & $-0.0567(-0.46)$ \\
\hline Net equity expansion & $0.170(0.63)$ & $0.215(0.81)$ & $-0.106(-0.80)$ & $-0.0523(-0.46)$ & $-0.132(-0.99)$ & $-0.0404(-0.48)$ \\
\hline Constant & $-0.0847(-1.49)$ & $-0.0557(-0.99)$ & $-0.0417(-1.49)$ & $-0.000875(-0.04)$ & $-0.0606^{*}(-2.14)$ & $-0.0011(-0.06)$ \\
\hline $\mathrm{r} 2$ & 0.0388 & 0.0731 & 0.1100 & 0.3386 & 0.1545 & 0.6677 \\
\hline
\end{tabular}

$t$ statistics in parentheses.

${ }^{*} p<0.05,{ }^{* *} p<0.01,{ }^{* * *} p<0.001$.

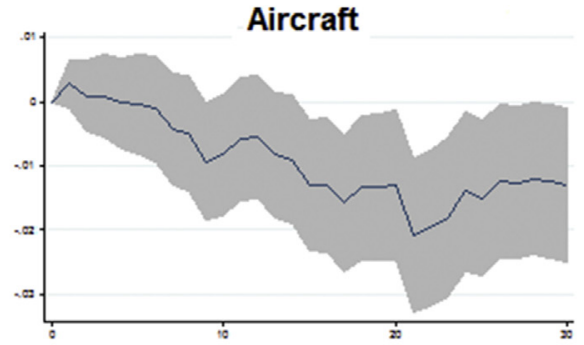

Steel
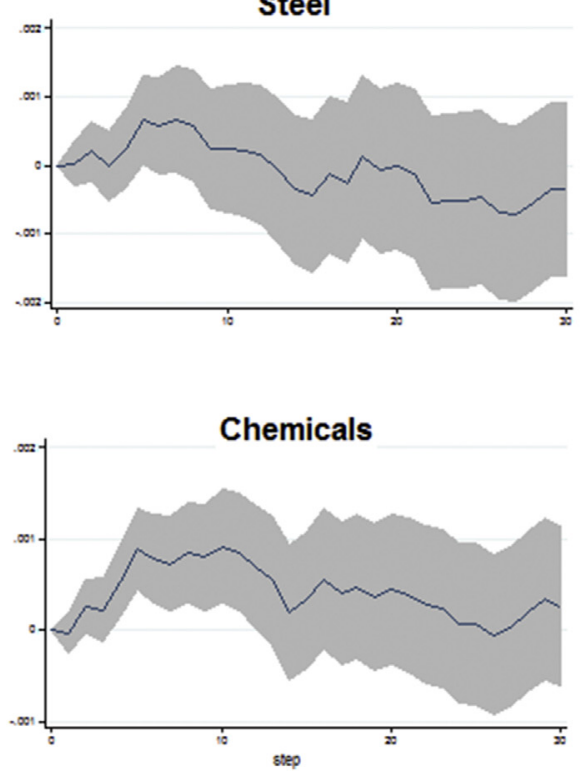

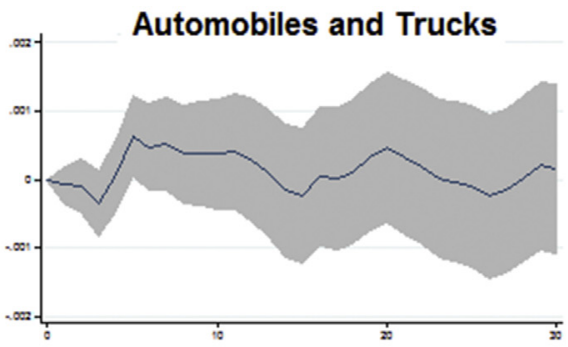

Precious metals
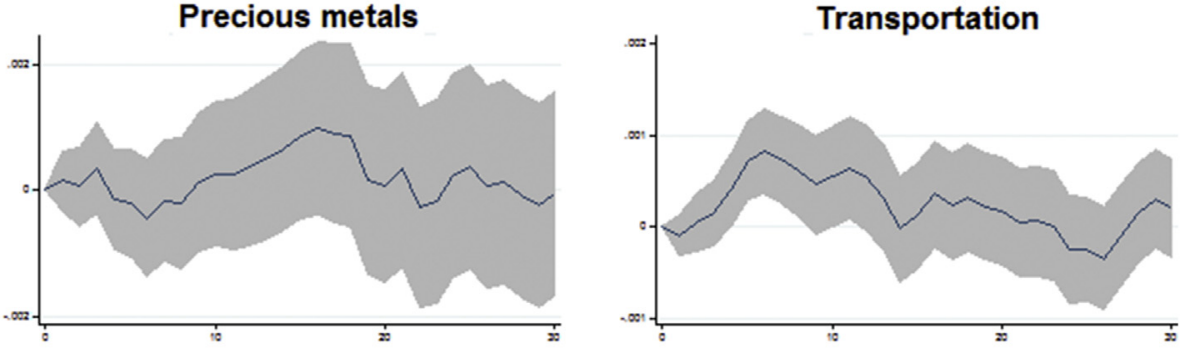

Consumer goods

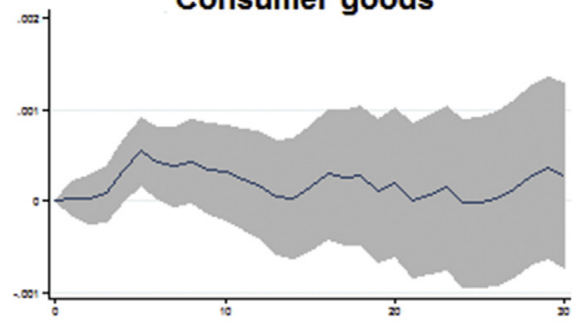

Transportation

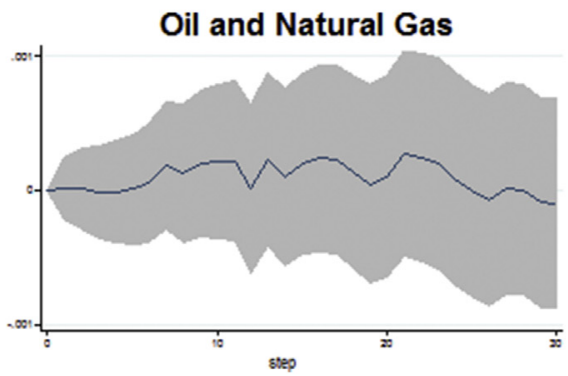

Fig. 3. Impulse responses of selected industries to an oil supply shock.

effect of oil shocks on each industry is captured by including the stock market index to the model. Our model then identifies the pure effect of each oil related shock on each industry's return taking out whatever irrelevant, including changes in the market index not related to the underlying oil shocks. ${ }^{5}$

\footnotetext{
${ }^{5} \mathrm{~A}$ very interesting analysis would be identifying each industry's contribution in changing the return of a specific industry after an oil related shock. However our variance decomposition analysis (Table 2) suggests that only a small part of the variations in industries' return is described by oil market which makes such analysis very difficult. Our results suggest that most of the variation in each industry's return is contributed by industry specific shocks and market shocks not related to the oil market.
}

To see the importance of market return index in explaining industry returns, the results from regressing each industry return on driving variables of stock market are shown in Tables 3 and 4 . In both tables the odd columns show the regression results of the industry return on the stock market variables excluding the index for aggregate stock market return and the even columns show the results from the same regression including aggregate return index. The coefficients on aggregate stock return are highly significant, both statistically and economically. It varies from as low as 0.5 for the case of gold to 1.3 for the case of steel. Interestingly, except for auto industry, the results show that including aggregate return in the regressions makes the coefficient on other variables statistically insignificant, while in the absence of it they are mostly statistically 

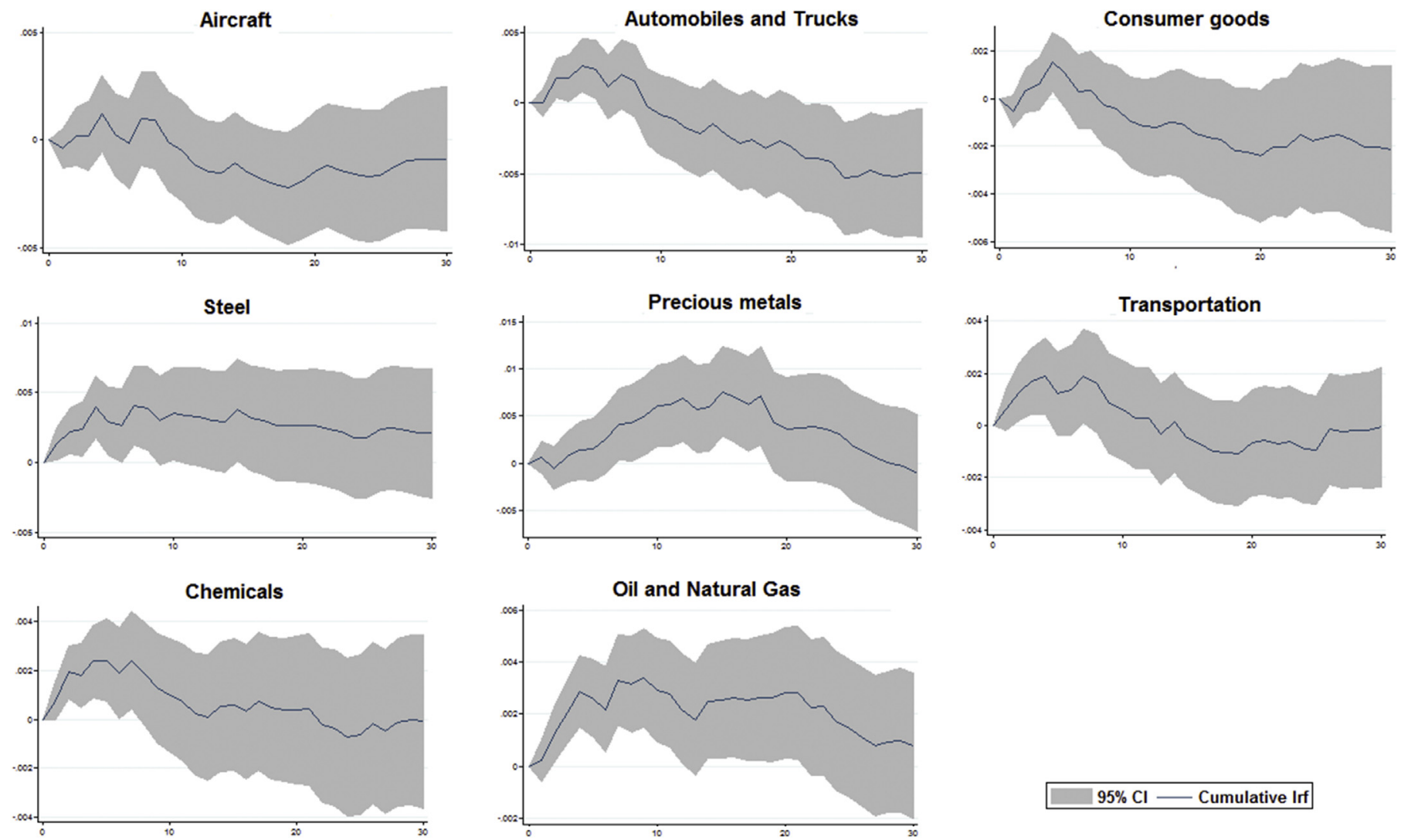

$95 \% \mathrm{Cl}-$ Cumulative Iff

Fig. 4. Impulse responses of selected industries to a global demand shock.
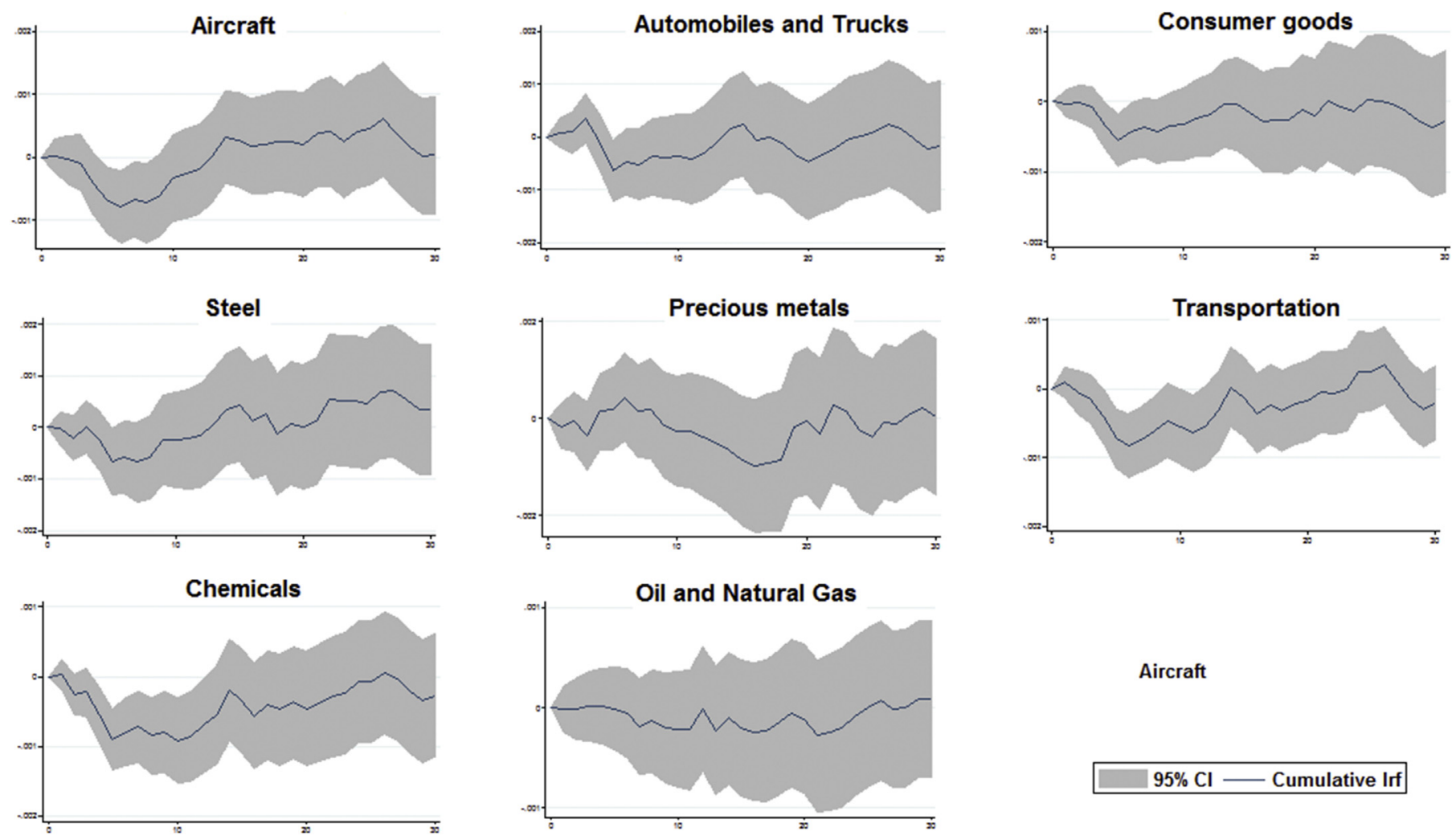

Aircraft

$95 \% \mathrm{Cl}-$ Cumulative Irf

Fig. 5. Impulse responses of selected industries to a speculative demand shock. 
Table 5

Variance decomposition of each industry return from estimation of model 4.

\begin{tabular}{|c|c|c|c|c|c|c|c|}
\hline & Oil use & Supply shock & Global demand shock & Speculation shock & Other oil shocks & Stock market shocks & Industry shock \\
\hline Oil & 0.0 & 5.0687 & 6.5499 & 2.5521 & 8.5068 & 21.3156 & 56.007 \\
\hline Aero & 0.011 & 6.7125 & 5.3515 & 5.5317 & 5.0433 & 37.0748 & 40.2862 \\
\hline Auto & 0.015 & 3.8152 & 10.0918 & 7.546 & 7.2716 & 35.2333 & 36.0422 \\
\hline hshld & 0.021 & 4.5404 & 7.0714 & 6.3848 & 6.5545 & 35.2036 & 40.2453 \\
\hline Steel & 0.023 & 5.0056 & 5.5713 & 7.1523 & 5.2367 & 42.8745 & 34.1596 \\
\hline Gold & 0.046 & 5.136 & 5.3152 & 5.3772 & 5.036 & 6.5946 & 72.541 \\
\hline Trans & 0.050 & 6.0408 & 4.8956 & 10.2999 & 5.4709 & 40.5653 & 32.7276 \\
\hline Chems & 0.103 & 7.4778 & 6.1056 & 8.3571 & 4.6688 & 44.0234 & 29.3674 \\
\hline
\end{tabular}

significant. This result confirms the importance of including aggregate return to the model that analyzes the responses of industries to oil market shocks.

Fig. 3 depicts the impulse response of the selected industries to a negative oil supply shock. The figure suggests that the industries that have negative response to supply shocks are not necessarily the oil intensive industries. The responses of industries to a positive global demand shock are graphed in Fig. 4. As shown in this figure, all the selected industries respond positively to a global demand shock. This finding is consistent with the fact that this shock is driven by an increase in the real economic activity which increases the demand for all industrial commodities. This figure also suggests that after a period, the return of all industries decreases to its initial level. This is because the higher price of oil decreases real economic activity and hence the demand for the industrial commodities declines. A positive shock to the speculative demand for oil, as shown in Fig. 5, affects negatively almost all of the industries with a delay. The exceptions are oil and precious metals industries. Overall, the results form impulse response analysis imply that the total cost of energy it is not enough to explain differences in the responses of real returns across industries, which is against the interpretation of oil price shocks as aggregate cost shocks.

Table 5 presents the FEVD, the contribution of each structural shock in forecasting industries return. The industries are sorted in their cost of oil for each dollar of their output. No systematic pattern in terms of oil use and the responses to an oil supply shock is seen. This suggests that the transmission of oil market shocks to the industries returns is driven not only by shifts in the cost of production but also by shifts in final demand for goods and services.

\subsection{Automobile and trucks}

The automobile and trucks industry is considered in the literature as being very responsive to oil price shocks and it is known as the most relevant channel through which oil shocks affect the economy (see e.g., $[16,35])$. The consensus in the literature is that, specially in the long-run, the oil market affects the manufacturing industries through the demand for final product by shifting toward high fuel efficiency. This is because an increase in gasoline price reduces demand for these industries through income effect. As these industries are not oil intensive, oil price shocks are shocks to the demand for their goods and services. For example, [29,35] provide evidence that the demand for full-size cars with low fuel efficiency collapses in response to an oil price increase. They explain that a permanent increase in gasoline price causes households to cut back on vehicle travel in the short run and then to make appropriate adjustments to their vehicle stock in the long run. Hughes et al. [21] report that the long-run price elasticity of gasoline consumption is seven times larger than the short-run elasticity. According to their empirical evidence, households drive more compared to early 1970 s, but they do so in vehicles that are more fuel efficient.
The empirical results of this paper show that, contrary to the common perception, depending on the cause behind the oil price increase, some of the strongest responses to oil shocks are found not only in the auto industry, but also in other industries like consumer goods and services. This result is in contrast with the view that oil price shocks are mostly cost shocks. The impulse responses show that an increase in the price of oil due to the production disruption has no significant effect on automobile stock price movements. An increase in global demand causes automobile shares to appreciate for about ten months. The effect of a positive shock to speculative demand for oil is negative after about 5 months of delay.

\subsection{Petroleum and natural gas}

[36] argues that oil industry enjoys a natural hedge against the negative supply shock since after a supply disruption the lower production and the higher price net out. This view is consistent with Fig. 3 where a small positive response to an oil supply shock could be noticed. After about 8 months, the response turns negative and still very small which could be justified with a reduction in demand for crude oil resulted from increased energy conservation. In contrast, a positive global demand shock causes a persistent increase in the petroleum and natural gas stock return. A speculative demand shock has a delayed negative effect on the value of this industry's stock. The small positive response to supply shocks and the negative response to speculative demand shocks could be an evidence that the oil industry does not appreciate from political disturbances driving production disruptions.

\subsection{Precious metals}

The impulse responses show that gold and silver industries appreciate significantly in response to a positive shock to global economic activity. An unanticipated increase in global demand driven by higher economic activity is taken as a signal of inflation and as a result the demand for gold and finally the gold industry appreciates. The other view about the effect of demand shock of gold industry which seems to be less strong is, during periods of high economic activity, investment in gold (increasing gold reserve) decreases as stock prices increase. However, unlike most of industries, this industry does not depreciate after a speculative demand shock. This result is consistent with the view that when stock prices fall in times of political uncertainty, investors increase their demand for precious metals.

\subsection{Steel}

Although metals are usually considered as highly energy intensive the main energy source for these industries is coal. For example, the total cost of coal for each dollar of revenue of iron and steel is eight cents, about twice as much as the cost of oil for this 
industry (Lee and $\mathrm{Ni}[29]$ ). Therefore, the cost effect of oil price shock on the steel industry is not as high as expected. On the demand side, an increase in price of oil raises the demand for steel in sectors like rig and pipeline building. This could explain why steel industry does not depreciate after a negative oil supply shock. The negative response to a positive speculative demand shock is due to the reduction in demand for steel and aluminum given the lowering effect of this shock on auto sales.

\section{Conclusion}

This paper provides a comprehensive analysis of the response of the U.S. real stock market return to the structural shocks in the global market for crude oil. On the aggregate level, the findings show that the responses to oil price shocks differ depending on the causes behind the shocks. The only underlying cause of an oil price shock that depreciates aggregate stock market is the shock to speculative demand for oil. A positive global demand shock raises the market return for ten months and lowers it afterwards. An oil supply shock does not affect significantly the aggregate stock market return. We argue that it is important to consider both stock and oil markets determinant variables in the analysis of the link between the two markets as omitting the stock market determinants from the analysis leads us to overestimate the contribution of oil shocks in the variations of the stock market return.

On the industry level, the estimation results show that the way oil price fluctuations affect each industry depends on the cause that drives the oil price shock, as well as on the industry characteristics. All industries appreciate after a global demand shock. This is because a positive global demand shock increases global real economic activity and also increases the demand for almost all industries. We did not find a systematic pattern for the responses of industries to an oil supply shock in terms of the level of oil-intensity of the industries. This could be an evidence that an increase in oil price due to a negative oil supply shock works through consumer spending as well as higher cost for production.

The results show that most of the industries depreciate in response to a speculative demand shock with some months of delay. The exception are precious metals and oil industries. This is consistent with the fact that speculative demand shocks are driven by expectations about the availability of future oil supplies. The results imply that the responses of industries' returns to an oil supply shock and to a speculative demand shock are positively correlated with the cost of oil for those industries. This suggests that cost side effect matters for the differences in the responses of real stock returns across industries. However, this effect is not enough to explain those differences since no such relation is found regarding the responses to a global demand shock. The estimation results suggest that both cost side dependence and demand side dependence on oil are important in explaining the sensitivity of industries' returns to oil price changes. More interestingly the demand side effect appears to be stronger.

\section{Acknowledgments}

We would like to thank seminar participants at the Department of Economics, Management and Quantitative Methods, University of Milan, Italy, the Department of Economics, Management and Statistics, University of Milan-Bicocca, Italy, the Department of Finance, Bocconi University, Milan, Italy, and the Fondazione Eni Enrico Mattei, Milan, Italy for useful comments on previous versions of this paper. The first author acknowledges financial support from Lombardy Advanced School of Economic Research.

\section{References}

[1] Alquist R, Kilian L. What do we learn from the price of crude oil futures? J Appl Econom 2010;25:539-73.

[2] Apergis N, Miller SM. Do structural oil-market shocks affect stock prices? J Energy Econ 2009;31:569-75.

[3] Arouri MEH. Does crude oil move stock markets in Europe? a sectoral investigation. Econ Model 2011;28:1716-25.

[4] Arouri MEH, Nguyen DK. Oil prices, stock markets and portfolio investment: evidence from sector analysis in Europe over the last decade. Energy Policy 2010;38(8):4528-39.

[5] Askaria H, Krichene N. An oil demand and supply model incorporating monetary policy. Energy J 2010;35(5):2013-21.

[6] Barsky RB, Kilian L. Do we really know that oil caused the great stagflation? a monetary alternative. In: Bernanke BS, Rogoff $\mathrm{K}$, editors. NBER macroeconomics annual. Cambridge, MA: MIT Press; 2002. p. 137-83.

[7] Charles MJ, Gautam K. Oil and the stock markets. J Financ 1996;51.

[8] Chen N, Roll R, Ross SA. Economic forces and the stock market. J Bus 1986;59(3):383-403.

[9] Chen S, He LY. Bubble formation and heterogeneity of traders: a multi-agent perspective. Comput Econ 2013;42:267-89.

[10] Ciner C. Energy shocks and financial markets: nonlinear linkages. Stud NonLinear Dyn Econom 2001;5:203-12.

[11] Dhaoui A, Khraief N. Empirical linkage between oil price and stock market returns and volatility: evidence from international developed markets. Discussion Paper No.2014-12 economics-ejournal 2014;12.

[12] Fama EF. Stock returns, expected returns, and real activity. J Financ 1990;45(2):1089-108.

[13] Galloa A, Masona P, Shapiroa S, Fabritius M. What is behind the increase in oil prices? analyzing oil consumption and supply relationship with oil price. Energy J 2010;35(10):4126-41.

[14] Gordon MJ, Shapiro E. Capital equipment analysis: the required rate of profit Manag Sci 1956;3(1):102-10.

[15] Goyal A, Welch I. A comprehensive look at the empirical performance of equity premium prediction. Rev Financ Stud 2008;21(4):1455-508.

[16] Hamilton JD. A neoclassical model of unemployment and the business cycle. J Polit Econ 1988;96:593-617.

[17] Hamilton JD. Causes and consequences of the oil shock of 2007-08. In Brookings papers on economic activity, (1, Spring); 2009. p. 215-61.

[18] Hamilton JD, Herrera AM. Oil shocks and aggregate macroeconomic behavior: the role of monetary policy. J Money Credit Bank 2004;36(2): $265-86$.

[19] He LY, Fana Y, Wei YM. Impact of speculator's expectations of returns and time scales of investment on crude oil price behaviors. Energy Econ 2009;31(1):77-84.

[20] Huang RD, Masulis RW, Stoll HR. Energy shocks and financial markets. J Futur Mark 1996;16:1-27.

[21] Hughes JE, Knittel CR, Sperling D. Evidence of a shift in the short-run price elasticity of gasoline demand. Energy J 2008;29(1):113-34.

[22] Ivanov V, Kilian L. A practitioner's guide to lag order selection for var impulse response analysis. Stud Nonlinear Dyn Econom 2005;9.

[23] KiHoon J, Bin P, Xiaohui Z. Capturing the impact of latent industry-wide shocks with dynamic panel model. Quantitative Finance Research Center; 2014. No. 347.

[24] Kilian L. Not all oil price shocks are alike: disentangling demand and supply shocks in the crude oil market. Am Econ Rev 2009a;99:1053-69.

[25] Kilian L, Lee TK. Quantifying the speculative component in the real price of oil: the role of global oil inventories. Int Money Financ 2014;42:71-87.

[26] Kilian L, Murphy DP. The role of inventories and speculative trading in the global market for crude oil. J Appl Econom 2014;29(3):454-78.

[27] Kilian L, Park C. The impact of oil price shocks on the U.S. stock market. Int Econ Rev 2009; 50:1267-87.

[28] Kling J. Oil price shocks and stock market behavior. J Portf Manag 1985;12(1): 34-9.

[29] Lee K, Ni S. On the dynamic effects of oil price shocks: a study using industry level data. J Monetary Econ 2002;9:823-52.

[30] Leeb H, Potscher BM. Can one estimate the conditional distribution of postmodel-selection estimators? Ann Stat 2006;34(5):2554-91.

[31] J. Linn. "Why do oil shocks matter? the importance of inter-industry linkages in U.S. manufacturing". Mimeo, University of Illinois at Chicago, 2006.

[32] Miller MH, Modigliani F. Dividend policy, growth and the valuation of shares. J Bus 1961;34(4):411-33.

[33] Odusami BO. Crude oil shocks and stock market returns. Appl Financ Econ 2009:19(4):291-303.

[34] Park J, Ratti RA. Oil price shocks and stock markets in the U.S. and 13 European countries. Energy Econ 2008;30(5):2587-608.

[35] Ramey VA, Vine DJ. Oil, automobiles, and the U.S. economy: how much have things really changed? NBER Macroecon Annu 2010;25.

[36] Ready RC. Oil prices and the stock market. University of Rochester; 2013. Working Paper, Available at SSRN 2140034 (2014).

[37] Sadorsky P. Oil price shocks and stock market activity. Energy Econ 1999;21: 449-69.

[38] Scholtens B, Boersen A. Stocks and energy shocks: the impact of energy accidents on stock market value. Energy J 2011;36(3):1698-702. 
[39] Scholtens B, Wang L. Oil risk in oil stocks. Energy J 2008;29:89-111.

[40] Scholtens B, Yurtsever C. Oil price shocks and European industries. J Energy Econ 2012;34:1187-95.

[41] Wang Y, Wua C, Yang L. Oil price shocks and agricultural commodity prices.
J Monetary Econ 2014;44:22-35.

[42] Wu H, Chen F, Zhang P. The heterogeneity of sectors and related efficiency of differential energy consumption. Appl Mech Mater 2013;291-294: 1290-6. 